\section{Rask innføring i de viktigste kommunikasjonsteorier}

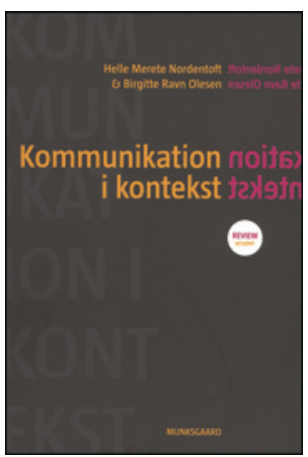

Helle Merete Nordentoft, Birgitte Ravn Olesen Kommunikation i kontekst

182 s, tab, ill. København: Munksgaard, 2014 Pris DKK 245

ISBN 978-87-628-1155-3

Denne danske utgivelsen retter seg mot studenter på bachelorog masternivå, samt profesjonelle som tar kommunikasjonskurs, særlig innen helsesektoren. Intensjonen er å bidra med en lærebok i kommunikasjon som er teoribasert, og som knytter teoriene til praktiske gjenkjennelige situasjoner helsearbeidere står $\mathrm{i}$.

Boken har et innledende, kortfattet vitenskapsteoretisk kapittel, etterfulgt av et kapittel som setter kunnskap om kommunikasjon inn i helsefaglig sammenheng. Her avlegges også New Public Management og statens rolle en visitt. Deretter følger kapitler om henholdsvis systemteori, dialogisk teori og mikrososiologisk teori, før siste kapittel tar for seg følelsenes betydning.

Dette er en nyttig bok for den som skal orientere seg i feltets fremherskende teorier. Man innser raskt hvor komplisert kommunikasjon er, samtidig viser boken nettopp hvordan forskjellige ståsteder (positivistisk, fenomenologisk, sosialkonstruktivistisk) og forskjellige forskningsmetoder er nødvendig og gjensidig berikende når man skal forstå hva som foregår når mennesker møtes i helsetjenesten. De to første kapitlene kan kanskje oppleves litt kompakte for en leser som er uvant med denne typen stoff. Til gjengjeld er særlig de tre teorikapitlene både lettleste og oversiktlige og har gode eksempler. Kapitlet om følelser kunne med fordel vært mer utviklet. De fleste referanseverk er med, men jeg savnet en henvisning til den østerriksk-amerikanske kommunikasjonsteoretikeren og familieterapeuten Paul Watzlawicks (1965) sentrale verk Pragmatics of Human Communication.

Så en refleksjon, eller kanskje et hjertesukk. Etter mitt skjønn dekker denne boken omtrent det leger bør vite om kommunikasjonsteori, men jeg tviler likevel på at vår faggruppe vil løpe og kjøpe. Og kanskje er vi bedre tjent med mer bruksanvisningspregede fremstillinger i første omgang? Men kommunikasjon er vitterlig et vesentlig element $i$ arbeidet vårt, og vi burde kjenne teorigrunnlaget for det like godt som teorigrunnlaget for bruken av røntgen. Samtidig er det interessant at slike bøker slår bedre an blant sykepleiere, selv om de også utøver et praktisk fag. En av bokens forfattere er sykepleier, og alle faglige vurderinger er gjort av helsefagarbeidere - men ingen av leger. Det virker ikke som forlaget tror stoffet har verdi for medisinere. Kan det være slik, og i så fall, hvorfor er det slik?

Pål Gulbrandsen

Professor, Universitetet i Oslo

\section{Råd og øvelser ved ryggvondt}

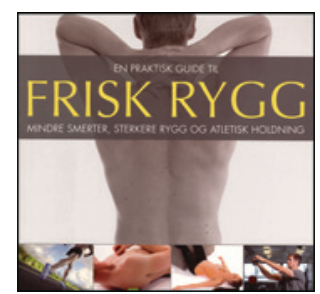

Anders Aasen Berget, Lennart Krohn-Hansen En praktisk guide til frisk rygg

Mindre smerter, sterkere rygg og atletisk holdning. 215 s, ill. Hafrsfjord: Jungelboken forlag, 2013. Pris NOK 349

ISBN 978-82-9988-513-3

En praktisk guide til frisk rygg henvender seg til personer med ryggplager. Hovedfokus er uspesifikke lave ryggplager (LBP). Forfatterne er fysioterapeuter.

Boken har 12 kapitler. Formatet er innbydende, layouten er pedagogisk, og det er rikelig med gode bilder og en del illustrasjoner. Den kan brukes som oppslagsbok, men har ikke stikkordregister. I hovedsak er den lettlest, men noen begreper er uklare og burde vært droppet. Det er mange, godt forklarte øvelser. Hva som er rett prioriteringsrekkefølge, oppleves uklart.

Boken har egen nettside med referanser som samtidig er lenker til sentrale, gode kilder - meget bra. Det er en rekke medforfattere, de fleste fysioterapeuter fra adekvate fagfelt, og også en psykolog. Jeg savner en lege med kunnskap om rygg.

Min hovedinnvending mot boken er at den gir seg ut for å være vitenskapsbasert, men at dette ofte svikter. Popularisering er krevende, og her lykkes man ikke helt. Forfatterne bringer inn mye egen synsing og egne begreper. «Friskhjulet» er et sentralt begrep i boken. «Friskhjulet skårer deg på hvordan hverdagen påvirker ryggen din». Her skal du skåre deg selv slik at hjulet «ruller godt». «Du kan også superkompensere, hvis du skårer svært godt». Dette er uklart. Spørsmålene for skåring er også uklare. For eksempel vil mange ha problemer med å avgjøre nivået på egne ryggkunnskaper, kroppsholdning, hva er «mye sukker og lite omega 3» osv. «Vi har funnet åtte nøkkelfaktorer for frisk rygg», som inngår i friskhjulet. Dette blir for upresist til at det kan kalles vitenskapsbasert.

Lite tillitsvekkende er det også når fysioterapeuten som er ansatt $i$ et firma som selger madrasser, har fått tre sider av boken der han understreker betydning av madrassvalg. Dette er ikke i overensstemmelse med europeiske retningslinjer for uspesifikke lave ryggplager.

Feil er det også når det står at kroppen reagerer øyeblikkelig og kraftig på selv de minste skader i ryggen. Hva med stumme osteoporotiske brudd og tidlige skjelettmetastaser? Nyoppstått impotens og sfinkterdysfunksjon er ikke tatt med i avsnittet om «Når du bør oppsøke lege». Det er ikke bra!

Etter disse negative betraktninger vil jeg fremheve optimismen som preger boken, og som leseren får del i. Det er mange gode øvelser og råd. Hvem bør så lese boken? Fagfolk er ikke målgruppen. Den kan anbefales til personer med uspesifikke ryggproblemer med en viss teoretisk skolering, og med god motivasjon for egeninnsats.

Helge M. Hartmann

Overlege, Avdeling for fysikalsk medisin og rehabilitering Sykehuset Levanger 